\title{
Agar Diffusion Test for Serum Cholinesterase Typing and Influence of Temperature on Dibucaine and Fluoride Numbers*
}

\author{
GEORGE LEE and J. C. ROBINSON
}

From the Biomedical Sciences Laboratory, Mental Retardation Program, National Institute of Child Health and Human Development, Bethesda, Maryland, U.S.A.

Some people exhibit prolonged apnoea following the administration of the muscle relaxant, suxamethonium. It has been shown that these people have an atypical serum cholinesterase. This atypical enzyme hydrolyses suxamethonium, and all other substrates against which it has been tested, less effectively than the usual type of serum cholinesterase (Kalow and Genest, 1957; Kalow and Staron, 1957; Kalow and Davies, 1959; Davies, Marton, and Kalow, 1960). The usual and the atypical phenotypes ( $U$ and $A$ ) of the enzyme can be distinguished by the use of the local anaesthetic, dibucaine, as an inhibitor under certain standard conditions. The percentage of inhibition is known as the dibucaine number or DN (Kalow and Genest, 1957). The usual enzyme is inhibited approximately $80 \%$ by dibucaine, and the atypical enzyme is inhibited approximately $20 \%$. A third phenotype of serum cholinesterase has been detected by means of the inhibitor technique. People of this intermediate type (phenotype I), like those of the usual type, are not suxamethonium sensitive: they have dibucaine numbers around 60 . The frequencies of these three phenotypes of serum cholinesterase are approximately equal among various populations in Europe and Canada, namely, about $97 \%$ for the $U$ phenotype, $3-4 \%$ for the I phenotype, and I in $4000(0.025 \%)$ for the A phenotype.

Family studies indicate that these types of serum cholinesterase are genetically determined (Kalow and Staron, 1957) by two co-dominant alleles. One gene, $E_{1}{ }^{u}$, controls the formation of the usual enzyme; the other gene, $E_{1} a$, directs the formation of the atypical enzyme. Therefore, subjects with

\footnotetext{
Received April 12, 1966.

*Part of this work was done while the authors were staff members of the National Institute of Arthritis and Metabolic Diseases, Bethesda, Maryland, U.S.A.
}

phenotypes $U$ and $A$ are homozygous for genes $E_{1} u$ and $E_{1}{ }^{a}$, respectively; subjects with phenotype I are heterozygous $\left(E_{1}^{u}, E_{1}^{a}\right)$.

Serum cholinesterase types can also be detected by using other differential inhibitors in the same manner as with dibucaine. One of these differential inhibitors is $\mathrm{RO}_{2}-0683$ (dimethylcarbamate of 2-hydroxy-5-phenylbenzyl trimethylammonium bromide, 'Roche'). This compound is more selective than dibucaine, but it does have the disadvantage of requiring pre-incubation with the enzyme (Kalow and Gunn, 1959; Kalow and Davies, 1959). Two other differential inhibitors are fluoride and succinylcholine. The percentages of inhibition by these compounds have been termed fluoride number or FN (Harris and Whittaker, 196I) and succinylcholine number (McComb, LaMotta, and Wetstone, 1965).

McComb et al. (1965) determined the succinylcholine numbers and the dibucaine numbers of 80 individuals and plotted dibucaine numbers against the succinylcholine numbers. The $A$ and I phenotypes were separated distinctly from each other into groups by both systems. The separation of $I$ and $U$ phenotypes was also clearly evident in the succinylcholine system, but the separation of the phenotypes in the dibucaine system was less distinct.

Harris and Whittaker (196I) used fluoride as an inhibitor and determined the fluoride numbers of sera of 285 people already classified by dibucaine numbers. When they plotted the dibucaine numbers against the fluoride numbers, it was observed that the groups of the $U$ and I phenotypes each had a small subgroup in which the fluoride inhibition was relatively less marked than the dibucaine inhibition. These fluoride resistant phenotypes were called UF and IF. Family studies revealed that the fluoride variant was also 
genetically determined. It is believed that its synthesis is directed by a third gene, $\mathrm{E}_{1} f$, at the same autosomal locus of genes $E_{1}^{u}$ and $E_{1}{ }^{a}$. There is also evidence for a fourth gene, $E_{1}{ }^{8}$, a 'silent' gene which is responsible for the complete absence of serum cholinesterase activity. The homozygote for $E_{1}{ }^{8}$ may be detected by the spectrophotometric method, but the heterozygote for $E_{1}{ }^{8}$ can be detected only by family studies (Liddell, Lehmann, and Silk, 1962; Simpson and Kalow, 1964).

The standard method for the differentiation of serum cholinesterase by determining dibucaine numbers spectrophotometrically is precise and highly reliable, but it is tedious when a large number of sera is to be tested. Harris and Robson (1963) devised a screening test, the agar diffusion test, which requires only simple equipment and permits rapid testing of a large number of sera. This method depends on the use of the differential inhibitor, Ro2-0683. The usual enzyme is inhibited almost completely by this compound, whereas the atypical enzyme is inhibited to a much lesser degree.

Two agar trays are used in the agar diffusion test: a control tray which contains no inhibitor and a tray which contains the inhibitor. Sera to be tested are suitably diluted and inserted into wells in the trays. After incubating overnight at $37^{\circ} \mathrm{C}$. the agar is flooded with a mixture of buffer, substrate, and a diazo-reagent for about two hours. In the control tray, sera with normal activity give a sharp-edged brown circular zone about $\mathrm{r} \cdot 3 \mathrm{~cm}$. in diameter. In the inhibitor tray two types of reactions can be observed: (I) negative-sera (phenotype $U$ ) which show marked inhibition resulting in faint, diffuse zones, and (2) positive-sera (phenotypes I and A) which yield sharp-edged, brown circular zones comparable in diameter to the corresponding zones in the control tray. In a 'blind' test on 250 sera on which the dibucaine numbers had becn determined spectrophotometrically, Harris and Robson (1963) found that 69 I and 14 A sera gave positive reactions and ${ }^{6} 67 \mathrm{U}$ sera gave negative reactions. There were no discrepancies in the results from the two tests.

Similarly, Simpson and Kalow (1965) used the agar diffusion test to screen about 6500 Brazilians (I000 families). When an inhibitor-resistant enzyme was detected in a family, dibucaine and fluoride numbers were determined on all members of the family. The results of the screening test were as follows. Of the $435 \mathrm{U}$ phenotypes, $78 \%$ were negative, $13 \%$ gave 'false positive' reactions, and $6 \%$ were 'undecided'. Two UF and one $\mathrm{F}$ phenotypes were negative. Of the 202
I phenotypes, $93 \%$ were positive, $3 \%$ gave 'fage negative' reactions, and $4 \%$ were 'undecide $\$$ One IF and four A phenotypes were positive.

This report is concerned with (I) further comparison of the agar diffusion test with the spectrophotometric method for typing serum cholinesterase, (2) the demonstration of the effect $\frac{\rho^{f}}{\delta^{\prime}}$ temperature on the inhibition of serum cholinesterase by dibucaine and sodium fluoride, and (F) family studies of dibucaine and fluoride resistant variants.

\section{Materials and Methods}

The population from which the blood samples we drawn was described by Dublin, Bernanke, Pitt, Masseil, Allen, and Amezcua (1964). It consisted of Caucasiants who had had rheumatic fever or clinically proven rhe matic heart disease in the past, their non-rheumatic spouses, and their children.

The screening test of Harris and Robson (1963) was used, with the modification that the zones of reaction were observed at half-hour intervals for two hours instead of the single observation after two hours.

The spectrophotometric tests were performed $26^{\circ} \mathrm{C}$., instead of $21-25^{\circ} \mathrm{C}$. as previously described (Kalow and Genest, 1957; Harris and Whittaker, 196 pr A Beckman DU spectrophotometer equipped wi thermal plates was used. DN was determined by the method of Kalow and Genest (1957), and FN whs determined by the method of Harris and Whittak (I96I).

The effect of temperature on the inhibition reactiog was studied by obtaining DN and FN values at 23,23 , 26, 30, and $37^{\circ} \mathrm{C}$. Except for the changes in temper ture, the usual procedures for DN and FN were used.

\section{Results and Discussion}

Of the plasmas of 320 couples (320 peope who had had rheumatic fever +320 non-rheumatic spouses) screened by the agar diffusion test, $6 \frac{8}{8}$ were classified as negative and 22 as positive $(3.4 \%)$. There were 13 positive reactors among the rheumatics, and 9 among the non-rheumatics.

Spectrophotometric determinations (DN anf FN) were performed on 383 plasmas random( selected from the 640 plasmas. 370 plasmas werf found to be $U$ or UF phenotype, and 13 were $\mathbb{R}$ All U or UF phenotype and all I phenotype wefe classified as negative and positive, respectivel by the agar diffusion test. In addition, $D$ and $\mathrm{FN}$ were determined on the 9 positive plasm which had not been included in this sample. A.II were found to be I phenotype. There was ne disparity between the classification with the agaf diffusion test and the typing with the spectrof photometric method. Since no A phenotype was observed with the spectrophotometric method, it is 
TABLE I

FREQUENCY OF SERUM CHOLINESTERASE PHENOTYPE I

\begin{tabular}{c|c|c|c|c}
\hline Method & $\begin{array}{c}\text { No. } \\
\text { Examined }\end{array}$ & $\begin{array}{c}\text { No. of } \\
\text { Phenotype } \\
\text { I }\end{array}$ & $\begin{array}{c}\text { Frequency } \\
\text { Phenotype } \\
\text { I (\%) }\end{array}$ & $\begin{array}{c}E_{I^{a} \text { Gene }} \\
\text { Frequency }\end{array}$ \\
\hline $\begin{array}{c}\text { Spectrophotometric } \\
\text { determination }\end{array}$ & 383 & 13 & 3.4 & 0.0170 \\
Agar diffusion test & 640 & 22 & 3.4 & 0.0172 \\
\hline
\end{tabular}

clear that plasmas classified as positive in the agar diffusion test were I phenotype.

The frequency of I phenotype for the population studied spectrophotometrically was found to be $3.4 \%$. Table I summarizes the frequencies calculated from the data from the agar diffusion test and from the spectrophotometric method. These results further substantiate the observations of Harris and Robson (1963) that the agar diffusion procedure is a reliable and accurate screening test for the classification of serum cholinesterase types.

The means and the standard deviations of DN and FN of plasmas of $392(370 \mathrm{U}+22 \mathrm{I})$ subjects surveyed by the spectrophotometric method were calculated and compared with the findings of Harris and Whittaker (196I). Table II shows that there is good agreement in the values of the dibucaine

\section{TABLE II}

COMPARISON OF DIBUCAINE NUMBERS OBTAINED BY PRESENT AUTHORS WITH THOSE OF HARRIS AND WHITTAKER (196I)

\begin{tabular}{c|c|c|c|c}
\hline \multirow{2}{*}{ Phenotype } & $\begin{array}{c}\text { No. of } \\
\text { Individuals }\end{array}$ & \multicolumn{2}{|c|}{ Dibucaine Number } & Investigators \\
\cline { 3 - 4 } & & Mean & SD & \\
\hline U & 370 & $79 \cdot 73$ & $1 \cdot 80$ & Present \\
I & 179 & 80.06 & $1 \cdot 56$ & Harris et al. \\
& 22 & 61.50 & $3 \cdot 33$ & Present \\
& 84 & $61 \cdot 93$ & $4 \cdot 17$ & Harris et al. \\
\hline
\end{tabular}

numbers. However, the means of our fluoride numbers in Table III are slightly lower than theirs. The initial suspicion was that the low fluoride inhibition was caused by the anticoagulant in the blood samples. It was believed possible that the ethylenediamine tetra-acetic acid (EDTA) might exert an indirect effect on the substrate-enzyme binding through formation of a chelation compound with a positively charged metallic ion in the plasma.

Fluoride numbers were determined on sera and plasmas collected in acid-citrate-dextrose (ACD), EDTA, heparin, or oxalate. From Table IV it can be seen that there was no significant difference among the means of sera and plasmas.
TABLE III

COMPARISON OF FLUORIDE NUMBERS OBTAINED BY PRESENT AUTHORS WITH THOSE OF HARRIS AND WHITTAKER (I96I)

\begin{tabular}{|c|c|c|c|c|}
\hline \multirow[t]{2}{*}{ Phenotype } & \multirow{2}{*}{$\begin{array}{c}\text { No. of } \\
\text { Individuals }\end{array}$} & \multicolumn{2}{|c|}{ Fluoride Number } & \multirow[t]{2}{*}{ Investigators } \\
\hline & & Mean & SD & \\
\hline $\begin{array}{l}\text { U } \\
\mathbf{I}\end{array}$ & $\begin{array}{r}370 \\
179 \\
22 \\
84\end{array}$ & $\begin{array}{l}56 \cdot 80 \\
61 \cdot 35 \\
44 \cdot 64 \\
44 \cdot 79\end{array}$ & $\begin{array}{l}2 \cdot 76 \\
3 \cdot 21 \\
2 \cdot 06 \\
4 \cdot 48\end{array}$ & $\begin{array}{l}\text { Present } \\
\text { Harris et al. } \\
\text { Present } \\
\text { Harris et al. }\end{array}$ \\
\hline
\end{tabular}

Since the determinations of dibucaine numbers and fluoride numbers in this study were performed at $26^{\circ} \mathrm{C}$. instead of $21-25^{\circ} \mathrm{C}$., as previously described (Kalow and Genest, 1957; Harris and Whittaker, I96I), studies were made of the effect of temperature on the inhibition of serum cholinestrase by dibucaine and sodium fluoride. When dibucaine numbers of a $U$ subject were determined at various temperatures, a linear relation of the inhibition numbers to temperature was observed (Fig. I). It can be seen from the graph that for an increment of one degree there is a decrease of nearly 0.6 in the dibucaine number $\left(\frac{\Delta \mathrm{DN}}{\Delta \mathrm{t}}\right)=0.6$ and a decrease of approximately $2 \cdot 2$ in the fluoride number $\left(\frac{\Delta \mathrm{FN}}{\Delta \mathrm{t}}=\mathbf{2 \cdot 2}\right)$. During the preparation of our manuscript, McComb et al. (1965) reported the temperature effect on the inhibition of serum cholinesterase by dibucaine and sodium fluoride.

TABLE IV

FLUORIDE NUMBERS OF SERA AND PLASMAS OF 6 SUBJECTS

\begin{tabular}{l|c|c|c|c|c}
\hline \multirow{2}{*}{ Subjects } & \multirow{2}{*}{ Sera } & \multicolumn{4}{|c|}{ Plasmas } \\
\cline { 3 - 6 } & & ACD & EDTA & Heparin & Oxalate \\
\hline J.C.R. & 56.41 & 55.56 & 57.00 & 56.57 & 55.36 \\
J.P. & 56.41 & 57.33 & 55.56 & 56.25 & 57.81 \\
S.V. & 54.29 & 54.39 & 54.84 & 54.54 & 55.77 \\
G.L. & 53.26 & 55.56 & 55.26 & 55.68 & 53.12 \\
F.A.B. & 58.14 & 56.32 & 56.79 & 55.13 & 57.59 \\
T.L. & 55.88 & 54.66 & 55.13 & 55.22 & 55.38 \\
\hline Mean & 55.73 & 55.64 & 55.76 & 55.57 & 55.50 \\
\hline
\end{tabular}

They found that dibucaine numbers were moderately affected by temperature, whereas fluoride numbers which averaged 59 at $25^{\circ} \mathrm{C}$. were 22 when measured at $37^{\circ} \mathrm{C}$, i.e. $\frac{\Delta \mathrm{FN}}{\Delta \mathrm{t}}=\frac{37}{12}=3 \cdot \mathrm{r}$. This is similar to our finding. The difference in the means of FN obtained by Harris and Whittaker (I96I) at $2 \mathrm{I}-25^{\circ} \mathrm{C}$. and by us at $26^{\circ} \mathrm{C}$. can possibly 


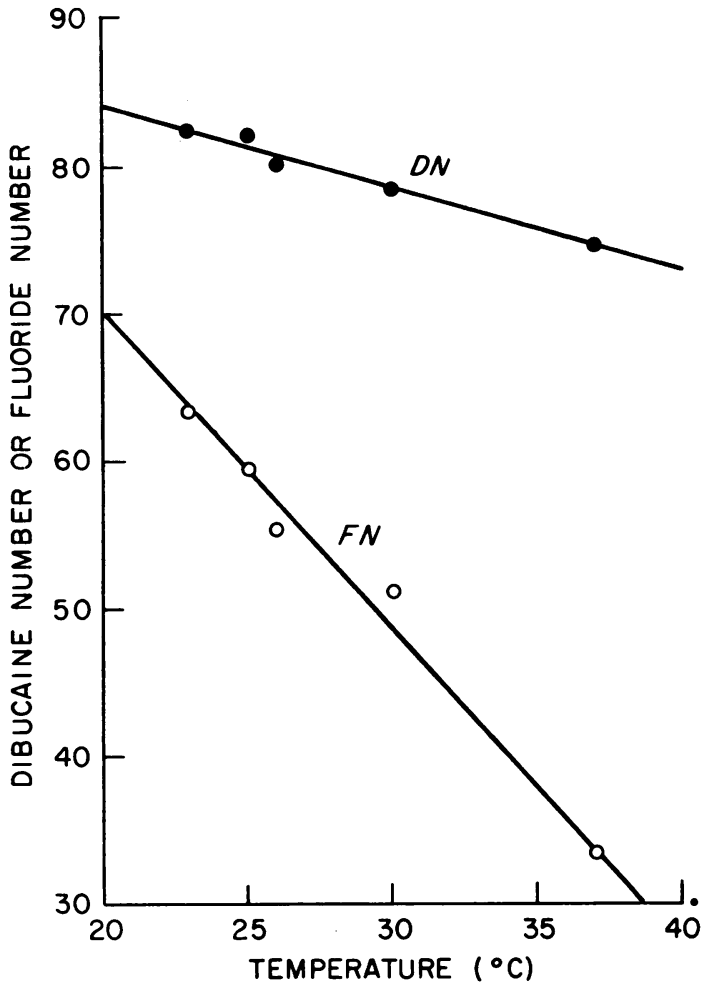

Fig. I. The effect of temperature on the dibucaine and fluoride numbers of serum from a subject with phenotype $U$. Each point represents the average of triplicate determinations. be attributed to the temperature effect. Th necessity for precise control of temperature in the determination of $\mathrm{FN}$ is emphasized by these data. $\stackrel{?}{\rightarrow}$

The bimodal distribution of dibucaine number in our material is evident in Fig. 2 and Fig. These data were obtained on the 383 random selected plasmas and the 9 positive plasmas detected in the screening tests. Subjects with $D N<\frac{6}{8}$ were classified phenotype I (Harris and Whittake I96I). The low fluoride numbers in this group afe also consistent with this phenotype. The famili data (Table V), which include all parents with $\mathrm{DN}<69$, support the designation of phenotype ${ }^{\circ}$ for $\mathrm{DN}<63$. Unfortunately, no family materia was available to check the critical portion of the distribution (DN 64-68).

Indistinct clustering of $U$ and UF phenotypes $\overrightarrow{\text { if }}$ shown in Fig. 3. The family data (Table VID which include all parents with $\mathrm{FN}<55$, suggest that the separation of the two groups occurs at approximately FN 53. The overlap of the groups is probably related to the differential effee of temperature on the fluoride numbers of the twg phenotypes (Fig. 4). The fluoride number of 9 UF individual was observed to be less affected by temperature $\left(\frac{\Delta \mathrm{FN}}{\Delta \mathrm{t}}=\mathrm{I} \cdot 5\right)$ than the fluoride numbe of a $\mathrm{U}$ individual $\left(\frac{\Delta \mathrm{FN}}{\Delta \mathrm{t}}=2 \cdot 6\right)$. It can be see from Fig. 4 that the separation of the fluoride numbers of the two phenotypes is less marked at

TABLE V

STUDY OF FAMILIES IN WHICH ONE PARENT WAS A DIBUCAINE VARIANT

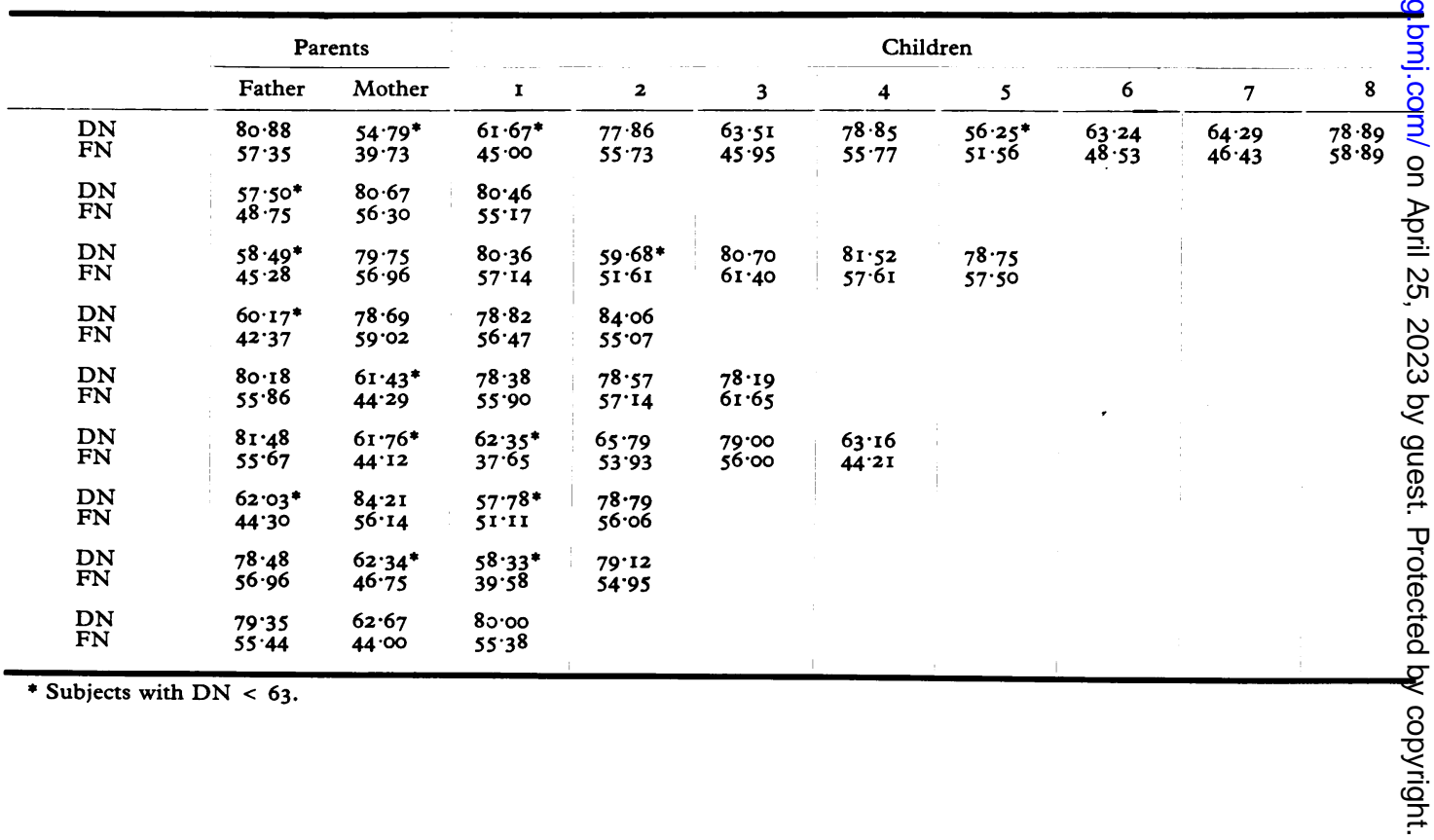




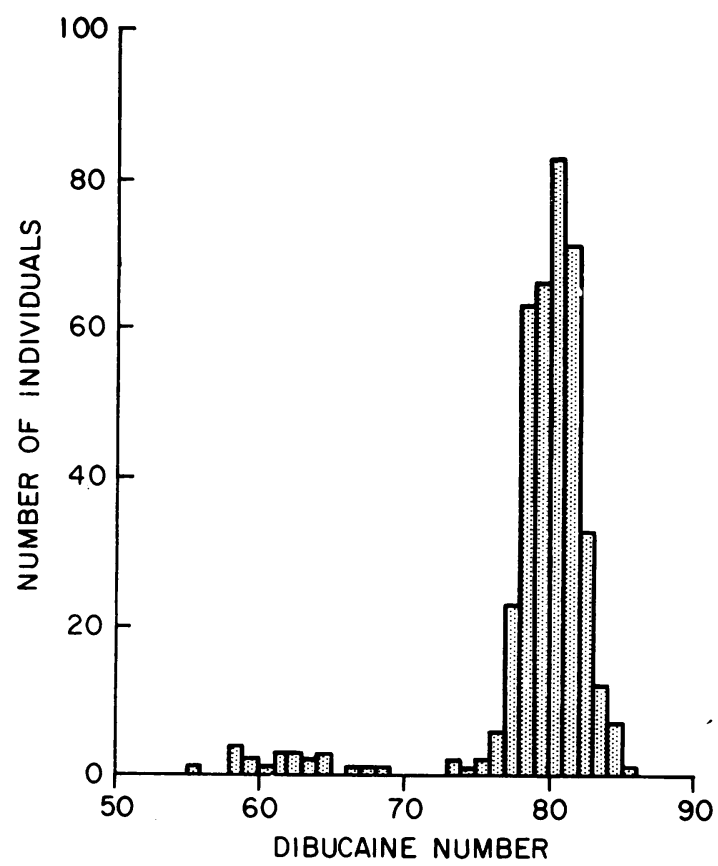

FIG. 2. Frequency distribution of $U$ and $I$ phenotypes. People with $\mathrm{DN}<69$ are considered to be phenotype I; the others, $U$.

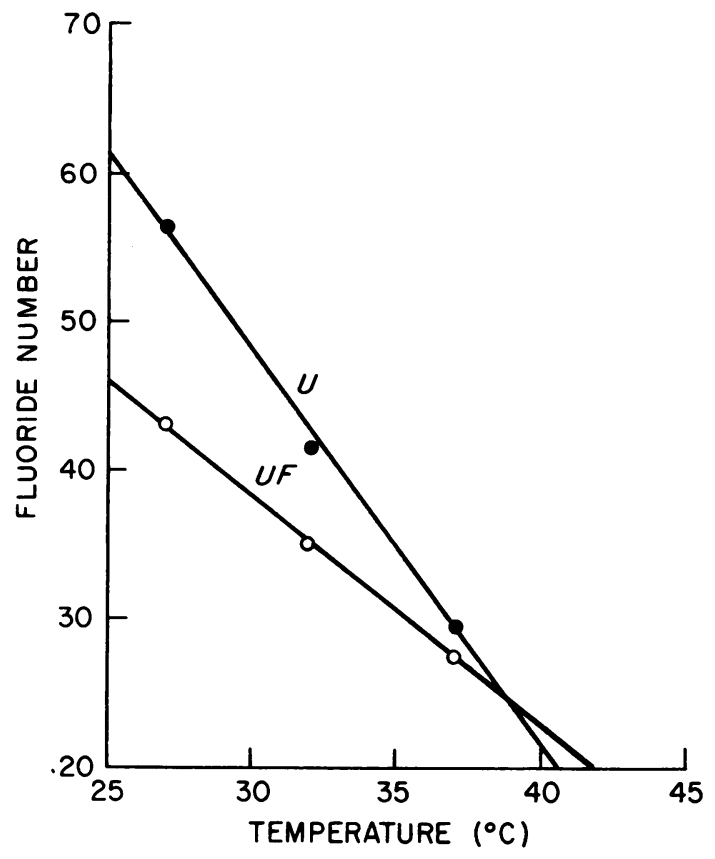

Frg. 4. The relation between temperature and fluoride numbers of two people, one of phenotype $U$, the other of phenotype UF.

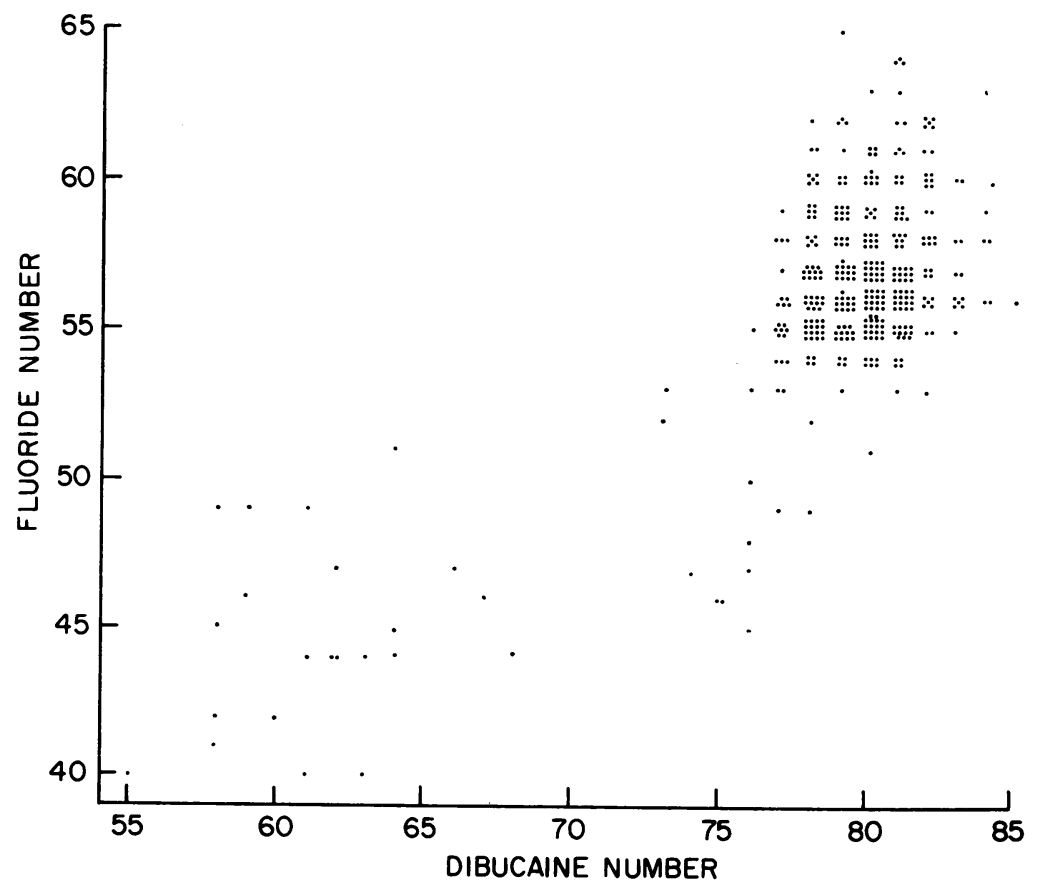

FIG. 3. Diagram illustrating the correlation of dibucaine and fluoride numbers in 392 people. The separation of $U$ and $I$ dibucaine variants is clear, but the distinction between $U$ and $U F$ is less evident. 
high temperatures. In fact, at $37-40^{\circ} \mathrm{C}$. the numbers are almost identical. Since our measurements were made at a higher temperature $\left(26^{\circ} \mathrm{C}\right.$.)

\section{TABLE VI}

STUDY OF FAMILIES IN WHICH ONE PARENT HAD FLUORIDE NUMBER 54 OR LESS

\begin{tabular}{|c|c|c|c|c|c|c|}
\hline & \multicolumn{2}{|c|}{ Parents } & \multicolumn{4}{|c|}{ Children } \\
\hline & Father & Mother & $\mathbf{I}$ & 2 & 3 & 4 \\
\hline $\begin{array}{l}\text { DN } \\
\text { DN }\end{array}$ & $\begin{array}{l}54.08 \\
80.61\end{array}$ & $\begin{array}{l}44.90^{*} \\
75.51\end{array}$ & $\begin{array}{l}53 \cdot 60 \\
79 \cdot 20\end{array}$ & $\begin{array}{l}52 \cdot 34^{*} \\
76 \cdot 64\end{array}$ & $\begin{array}{l}52 \cdot 38^{*} \\
76.87\end{array}$ & \\
\hline $\begin{array}{l}\text { FN } \\
\text { DN }\end{array}$ & $\begin{array}{l}55 \cdot 36 \\
80 \cdot 36\end{array}$ & $\begin{array}{l}46.03^{*} \\
74.60\end{array}$ & $\begin{array}{l}59 \cdot 21 \\
80 \cdot 26\end{array}$ & $\begin{array}{l}57 \cdot 29 \\
78 \cdot 12\end{array}$ & $\begin{array}{l}50 \cdot 00^{*} \\
77 \cdot 36\end{array}$ & \\
\hline $\begin{array}{l}\text { FN } \\
\text { DN }\end{array}$ & $\begin{array}{l}46 \cdot 74^{*} \\
76 \cdot 90\end{array}$ & $\begin{array}{l}57 \cdot 14 \\
81 \cdot 32\end{array}$ & $\begin{array}{l}49 \cdot 16^{*} \\
77 \cdot 10\end{array}$ & $\begin{array}{l}48 \cdot 18^{*} \\
77 \cdot 27\end{array}$ & & \\
\hline $\begin{array}{l}\text { FN } \\
\text { DN }\end{array}$ & $\begin{array}{l}46.96^{*} \\
73.91\end{array}$ & $\begin{array}{l}56.99 \\
78.49\end{array}$ & $\begin{array}{l}49.03^{*} \\
72.55\end{array}$ & $\begin{array}{r}58.39 \\
83.90\end{array}$ & & \\
\hline $\begin{array}{l}\text { FN } \\
\text { DN }\end{array}$ & $\begin{array}{l}48 \cdot 56^{*} \\
78.03\end{array}$ & $\begin{array}{l}60 \cdot 00 \\
80 \cdot 00\end{array}$ & $\begin{array}{l}55 \cdot 04 \\
82 \cdot 17\end{array}$ & $\begin{array}{l}51 \cdot 61^{*} \\
75 \cdot 27\end{array}$ & $\begin{array}{l}56.99 \\
80.65\end{array}$ & $\begin{array}{l}55.08 \\
83.05\end{array}$ \\
\hline $\begin{array}{l}\text { FN } \\
\text { DN }\end{array}$ & $\begin{array}{l}50 \cdot 00^{*} \\
76.00\end{array}$ & $\begin{array}{l}61 \cdot 25 \\
80 \cdot 00\end{array}$ & $\begin{array}{l}53 \cdot 09 \\
77 \cdot 78\end{array}$ & & & \\
\hline $\begin{array}{l}\text { FN } \\
\text { DN }\end{array}$ & $\begin{array}{l}52 \cdot 22^{*} \\
73.33\end{array}$ & $\begin{array}{l}57 \cdot 50 \\
77 \cdot 50\end{array}$ & $\begin{array}{l}52 \cdot 3 I^{*} \\
78 \cdot 46\end{array}$ & $\begin{array}{l}56 \cdot 90 \\
81 \cdot 03\end{array}$ & & \\
\hline $\begin{array}{l}\text { FN } \\
\text { DN }\end{array}$ & $\begin{array}{l}52.83 \\
82.08\end{array}$ & $\begin{array}{l}61 \cdot 03 \\
79 \cdot 49\end{array}$ & $\begin{array}{l}59 \cdot 00 \\
81 \cdot 00\end{array}$ & $\begin{array}{l}55.06 \\
80.81\end{array}$ & & \\
\hline $\begin{array}{l}\text { FN } \\
\text { DN }\end{array}$ & $\begin{array}{l}53.00 \\
73.00\end{array}$ & $\begin{array}{r}55 \cdot 56 \\
81 \cdot 48\end{array}$ & $\begin{array}{l}54 \cdot 17 \\
82 \cdot 50\end{array}$ & & & \\
\hline $\begin{array}{l}\text { FN } \\
\text { DN }\end{array}$ & $\begin{array}{l}53.03 \\
77.27\end{array}$ & $\begin{array}{l}57 \cdot 14 \\
79 \cdot 12\end{array}$ & $\begin{array}{l}49.33^{*} \\
78.67\end{array}$ & $\begin{array}{l}50 \cdot 91^{*} \\
79.39\end{array}$ & & \\
\hline $\begin{array}{l}\text { FN } \\
\text { DN }\end{array}$ & $\begin{array}{l}55.32 \\
80.85\end{array}$ & $\begin{array}{l}53 \cdot 33 \\
79 \cdot 17\end{array}$ & $\begin{array}{l}53.21 \\
78.90\end{array}$ & $\begin{array}{l}53.09 \\
81 \cdot 48\end{array}$ & & \\
\hline $\begin{array}{l}\text { FN } \\
\text { DN }\end{array}$ & $\begin{array}{l}53 \cdot 36 \\
76 \cdot 75\end{array}$ & $\begin{array}{l}64 \cdot 29 \\
81 \cdot 43\end{array}$ & $\begin{array}{l}59.42 \\
84.06\end{array}$ & $\begin{array}{r}54 \cdot 93 \\
77 \cdot 46\end{array}$ & & \\
\hline $\begin{array}{l}\text { FN } \\
\text { DN }\end{array}$ & $\begin{array}{l}53 \cdot 61 \\
80 \cdot 12\end{array}$ & $\begin{array}{r}54 \cdot 19 \\
80 \cdot 18\end{array}$ & $\begin{array}{l}54 \cdot 40 \\
82 \cdot 40\end{array}$ & $\begin{array}{l}55 \cdot 17 \\
79 \cdot 31\end{array}$ & & \\
\hline $\begin{array}{l}\text { FN } \\
\text { DN }\end{array}$ & $\begin{array}{r}57 \cdot 38 \\
8 I \cdot 15\end{array}$ & $\begin{array}{r}53.66 \\
80.49\end{array}$ & $\begin{array}{r}53.54 \\
82.68\end{array}$ & & & \\
\hline $\begin{array}{l}\text { FN } \\
\text { DN }\end{array}$ & $\begin{array}{l}54.02 \\
78 \cdot 16\end{array}$ & $\begin{array}{r}56 \cdot 25 \\
77.50\end{array}$ & $\begin{array}{l}59 \cdot 26 \\
79 \cdot 63\end{array}$ & $\begin{array}{l}56 \cdot 32 \\
81 \cdot 49\end{array}$ & & \\
\hline $\begin{array}{l}\text { FN } \\
\text { DN }\end{array}$ & $\begin{array}{l}54 \cdot 17 \\
80 \cdot 00\end{array}$ & $\begin{array}{l}54.02 \\
79.31\end{array}$ & $\begin{array}{l}55 \cdot 46 \\
82 \cdot 35\end{array}$ & $\begin{array}{l}55.96 \\
80.73\end{array}$ & $\begin{array}{l}55.08 \\
81.02\end{array}$ & \\
\hline $\begin{array}{l}\text { FN } \\
\text { DN }\end{array}$ & $\begin{array}{l}54 \cdot 17 \\
80.83\end{array}$ & $\begin{array}{l}57 \cdot 50 \\
77.50\end{array}$ & $\begin{array}{l}56 \cdot 12 \\
81 \cdot 63\end{array}$ & $\begin{array}{l}61 \cdot 40 \\
82 \cdot 46\end{array}$ & $\begin{array}{l}55 \cdot 56 \\
84.44\end{array}$ & $\begin{array}{l}56 \cdot 12 \\
80.61\end{array}$ \\
\hline $\begin{array}{l}\text { FN } \\
\text { DN }\end{array}$ & $\begin{array}{l}55 \cdot 26 \\
80 \cdot 70\end{array}$ & $\begin{array}{l}54 \cdot 25 \\
79 \cdot 74\end{array}$ & $\begin{array}{r}53 \cdot 60 \\
82 \cdot 40\end{array}$ & $\begin{array}{l}55.08 \\
83.05\end{array}$ & & \\
\hline $\begin{array}{l}\text { FN } \\
\text { DN }\end{array}$ & $\begin{array}{l}54 \cdot 37 \\
79 \cdot 61\end{array}$ & $\begin{array}{l}57 \cdot 31 \\
79 \cdot 31\end{array}$ & $\begin{array}{l}52 \cdot 38^{*} \\
80.95\end{array}$ & $\begin{array}{l}53 \cdot 70 \\
82 \cdot 10\end{array}$ & $\begin{array}{r}52.75 \\
83.51\end{array}$ & \\
\hline $\begin{array}{l}\text { FN } \\
\text { DN }\end{array}$ & $\begin{array}{l}57.97 \\
82.61\end{array}$ & \begin{tabular}{|l|}
54.44 \\
78.89
\end{tabular} & $\begin{array}{l}54.55 \\
80.81\end{array}$ & $\begin{array}{l}52.83 \\
79 \cdot 58\end{array}$ & & \\
\hline
\end{tabular}

* Subjects with FN $<53$.

than that at which previous investigators have made their determinations $\left(2 \mathrm{I}-25^{\circ} \mathrm{C}\right.$.), a less distinct separation of phenotypes was observed in our material.

\section{Summary}

The results in the cholinesterase typing of 392 plasmas by the agar diffusion test were fully confirmed by the spectrophotometric determination of dibucaine numbers.

The main advantage of the agar diffusion test is the simplicity with which dibucaine variants can $\mathbb{Q}$ be detected. In our hands the test was of no value on in detecting the UF phenotype.

The dibucaine number and the fluoride number. were found to be inverse functions of temperature. $\overrightarrow{\vec{\omega}}$ The change in fluoride number per degree was roughly 4 times as great as the change in dibucaine $\overline{3}$ number. Furthermore, the magnitude of the change of the fluoride number with temperature was greater with the U than with the UF plasmas.

By using the spectrophotometric method, the distinction between $U$ and I dibucaine variants ${ }_{-}$ was apparent at $26^{\circ} \mathrm{C}$., but the $U$ and UF groups 3 could not be clearly separated. Since previous investigators have determined fluoride numbers at 9 $2 \mathrm{I}-25^{\circ} \mathrm{C}$., and since the distinction between $\mathrm{U}$ and $\vec{\bullet}$ $\mathrm{UF}$ is less marked when fluoride numbers are determined at raised temperatures, our failure to distinguish clearly these phenotypes may be relatedo to the temperature effect.

The authors wish to thank Dr. T. D. Dublin, National $\overrightarrow{0}$ Institute of Arthritis and Metabolic Diseases, for making3 blood samples available in this study, and Dr. W. E. Scott of Hoffman LaRoche Co. for the generous supplyo of $\mathrm{RO}_{2}-0683$.

\section{REFERENCES}

Davies, R. O., Marton, A. V., and Kalow, W. (1960). The action of normal and atypical cholinesterase of human serum upon $a$ series of esters of choline. Canad. F. Biochem., 38, 545.

Dublin, T. D., Bernanke, A. D., Pitt, E. L., Massell, B. F., Allen F. H., Jr., and Amezcua, F. (1964). Red blood cell groups andN $\mathrm{ABH}$ secretor system as genetic indicators of susceptibility to rheumatic fever and rheumatic heart disease. Brit. med. $\mathcal{F}$., 2,, $\mathcal{U}$

Harris, H., and Robson, E. B. (1963). Screening tests for the "atypical" and "intermediate" serum-cholinesterase types. Lancet, $2,218$.

- , and Whittaker, M. (196r). Differential inhibition of humanc serum cholinesterase with fluoride: recognition of two new phenotypes. Nature (Lond.), 191, 496.

Kalow, W., and Davies, R. O. (1959). The activity of various esterase inhibitors towards atypical human serum cholinesterase. (D) Biochem. Pharmacol., 1, 183.

- , and Genest, K. (1957). A method for the detection of atypical forms of human serum cholinesterase. Determination
of dibucaine numbers. Canad. . Biochem., 35, 339. 
- and Gunn, D. R. (1959). Some statistical data on atypical cholinesterase of human serum. Ann. hum. Genet., 23, 239.

, and Staron, N. (1957). On distribution and inheritance of atypical forms of human serum cholinesterase, as indicated by dibucaine numbers. Canad. F. Biochem., 35, 1305.

Liddell, J., Lehmann, H., and Silk, E. (I962). A "silent" pseudocholinesterase gene. Nature (Lond.), 193, 561.

McComb, R. B., LaMotta, R. V., and Wetstone, H. J. (1965).
Procedure for detecting atypical serum cholinesterase using o-nitrophenyl-butyrate as substrate. Clin. Chem., 11, 645.

Simpson, N. E., and Kalow, W. (1964). The "silent" gene for serum cholinesterase. Amer. F. hum. Genet., 16, 180.

, and - (1965). Comparisons of two methods for typing of serum cholinesterase and prevalence of its variants in a Brazilian population. ibid., 17, 156 . 